\title{
UN CARPINTERO POBLANO
}

En el tomo 15 de Duplicados de Reales Cédulas del Archivo General de la Nación, expedientes 453 a 456, se encuentra la documentación de la cimbra sobre la cual se construyó la cúpula de la Catedral de Puebla. Un nuevo artífice aparece en la obra del templo máximo poblano, si bien es un oscuro carpintero. El canónigo racionero Don Andrés de Luey, que era el obrero mayor, juez tesorero, receptor, cobrador y pagador de la Catedral, envió un requerimiento para que "las Justicias de la Gobernación de esta Nueva España compelan a Juan Bautista Pedrete a que vaya a la Ciudad de los Angeles a quitar la cimbria de la iglesia mayor conforme a su obligación" y que presentase los autos y papeles al respecto.

El maestro Pedrete, que andaba en Amilpas, con mucho trabajo, contestó enfadado que no tenía papeles ningunos en que se le obligase a quitar la cimbra "ni hubo más que haberle mandado el señor don Juan de Palafox y Mendoza que hiciese unas trazas o formas de una cimbria que, quedando en el aire, se pudiese fabricar sobre ella, y habiéndola hecho, le dio dos mil pesos por premio de su trabajo y nueva inventiva, y aunque merecía mayor cantidad, se content $\delta$ con la referida por hacer servicio a ambas Majestades, como lo ha hecho en otras obras públicas". Como esto pasaba en marzo de 1651, año en que ya no estaba Palafox, el racionero prefirió solucionar el asunto dando a Pedrete quinientos pesos para que desbaratase la cimbra. Sabemos, pues, que cuando se dedicó la Catedral por el Ilustrísimo señor Palafox en 1649, aún no lucia el interior de la cúpula, ocupada por la "nueva inventiva" de los andamios del maestro carpintero Pedrete. (Agradezco la comunicación del dato al señor Prof. José Miranda).

F. de la $M$. 